University of Nebraska - Lincoln

DigitalCommons@University of Nebraska - Lincoln

Architecture Program: Faculty Scholarly and

Creative Activity

Architecture Program

2006

\title{
Authorship of The Most Notable Antiquity (1655): Inigo Jones and Early Printed Books
}

Rumiko Handa

University of Nebraska-Lincoln, rhanda1@unl.edu

Follow this and additional works at: https://digitalcommons.unl.edu/arch_facultyschol

Part of the Architecture Commons

Handa, Rumiko, "Authorship of The Most Notable Antiquity (1655): Inigo Jones and Early Printed Books" (2006). Architecture Program: Faculty Scholarly and Creative Activity. 16.

https://digitalcommons.unl.edu/arch_facultyschol/16

This Article is brought to you for free and open access by the Architecture Program at DigitalCommons@University of Nebraska - Lincoln. It has been accepted for inclusion in Architecture Program: Faculty Scholarly and Creative Activity by an authorized administrator of DigitalCommons@University of Nebraska - Lincoln. 


\title{
Authorship of The Most Notable Antiquity (1655): Inigo Jones and Early Printed Books ${ }^{1}$
}

\author{
Rumiko Handa
}

$\prod \begin{aligned} & \text { He Most Notable Antiquity of Great Britain, Vulgarly Called Stone- } \\ & \text { Heng, on Salisbury Plain (London, 1655; Stone-Heng hereafter) is }\end{aligned}$ the only publication associated with Inigo Jones (1573-1652), Surveyor for Prince Henry, King James I, and King Charles I. ${ }^{2}$ However, the precise nature of Jones's contribution to this work is much debated, his authorship being challenged. Jones's supposed lack of learning has led scholars to believe that Jones had little or no involvement in the work. However, new evidence suggests that Jones possessed far more extensive learning than has previously been credited to him. Indeed, this essay will show the nature of collaboration between the master, Jones, and his assistant, Webb: Jones was often responsible in constructing an argument and supporting it with printed sources, while Webb provided bibliographical details.

1. Research was made possible by the Huntington Library Gilbert and Ursula Farfel Fellowship. Newberry Library Consortium Grants and University of Nebraska-Lincoln Undergraduate Creative and Research Enhancement Grants provided additional support. The author also thanks the following libraries and their librarians: Worcester College Library, Oxford University; British Library; Guildhall Library; St. Bride's Library; Canadian Centre for Architecture Library; University of Toronto Library; Houghton Library, Harvard University; Getty Research Institute Library; University of Chicago Library; University of Kansas Library; and University of Nebraska-Lincoln Library.

2. Inigo Jones, The Most Notable Antiquity of Great Britain, Vulgarly Called Stone-Heng on Salisbury Plain (London, 1655), 1. The second edition (London, 1725) has an identical text but different setting of type and pagination.

Rumiko Handa (2712 Sumner Street, Lincoln, NE 68502; rhanda1@unl.edu) is associate professor of architecture at the University of Nebraska-Lincoln. 
Stone-Heng presented an erroneous conclusion that Stonehenge was a Roman temple dedicated to Coelus. It asserted that the circular and roofless form represented the heavens, of which Coelus was the god, and regarded the crude cut of the standing stones as Tuscan, the most primitive of all orders, appropriate for the first of all deities. The account of how Jones came to interpret the megalith has been generally accepted. ${ }^{3}$ In 1620 James I took an interest in Stonehenge while staying at nearby Wilton, the seat of William Herbert, Earl of Pembroke and then Lord Chamberlain. Jones, then five years into his term as Surveyor of the King's Works, was summoned to study the structure and inform the King of its origins and significance. The extent to which Jones was responsible for the 1655 published interpretation is not clear, however. Thirty-five years had passed since James I's summons, and three years since Jones's death. John Webb (1611-72), Jones's assistant since 1628, claimed in the book's preface that he himself "compose[d] this Treatise" from the master's "some few indigested notes." "Webb also wrote that Jones's "Notes were not found, much less Stone-Heng restored written, until long after his Death" in a later publication. ${ }^{5}$ The publisher of Stone-Heng's second edition (1725) changed the book's title from...on Salisbury plain. Restored by Inigo Jones to... on Salisbury plain restored. By Inigo Jones, possibly intending to reclaim Jones's authorship: While "by" in the original title referred only to the verb "restored," "by" in the new title clearly positions Jones as the author of the text.

Neither Graham Parry nor Stuart Piggott expanded the authorship discussion beyond Webb's statement when writing introductions to modern facsimile reproductions of the 1655 original and the 1725 second editions in 1972 and 1971, respectively. ${ }^{6}$ In 1978, Alan Anderson Tait brought the question to the forefront and concluded that Webb provid-

3. Stone-Heng (1655), $1-2$.

4. "To the Favourers of Antiquity" signed J.W., Stone-Heng (1655), immediately preceding p. 1 .

5. John Webb, A Vindication of Stone-Heng Restored ... 2nd ed. (London, 1725), 118. First published in 1665 .

6. Stuart Piggott, "Introduction," Stone-Heng [by] Inigo Jones, Chorea Gigantum [by] Walter Charleton, [and] A Vindication [by] John Webb, London, 1725 (London: Gregg International Publishers Limited, 1971); Graham Parry, "Introductory Note," The Most Notable Antiquity of Great Britain Vulgarly Called Stonehenge by Inigo Jones (London: Scolar Press, 1972). 


\section{Authorship of The Most Notable Antiquity}

ed the historical and literary references and Jones the geometrical analysis of the megalith's circular plan. ${ }^{7}$ More recently, Christy Anderson credited most of the argument to Webb, stating that the pattern of reasoning was too scholarly to be that of Jones. ${ }^{8}$ Vaughan Hart regards Stone-Heng as a document that reflects Jones's thought processes but states that it is impossible and unnecessary to come to any conclusion about the authorship because the master and the assistant worked so closely together. ${ }^{9}$

Nevertheless, I submit that the authorship of Stone-Heng is a key to understanding Jones's work. When we reexamine Jones's opus with the Stonehenge interpretation in mind, the symbolism of James I as Coelus emerges as a recurring theme. It is found not only in this book but also, arguably, in Jones's design for the King's catafalque of 1625 and in his design of the scenery for the masque Coelum Britannicum of 1634. While James I was often associated with King Solomon, other deities also represented the monarch, including Neptune in Ben Jonson's masque Neptune's Triumph for the Return of Albion (1625).${ }^{10}$ The symbolism of Coelus is an aspect of Jones's classicism that has previously been overlooked.

Assigning the line of argument in Stone-Heng to Jones will expand our knowledge of his intellectual sources, both in terms of the number and the range of subjects. We, on the one hand, already have a list of seventy treatises associated to Jones's reading, predominantly on architecture and related disciplines (art, mechanics, fortifications), including forty-six that have survived from his library and an additional twentytwo he mentioned in handwritten marginalia of these books. ${ }^{11}$ On the

7. A. A. Tait, "Inigo Jones's 'Stone-Heng," Burlington Magazine, March 1978, $154^{-8}$.

8. Christy Anderson, "Inigo Jones's Library and the Language of Architectural Classicism in England, 1580-1640" (Ph.D. diss., Massachusetts Institute of Technology, 1993), 128.

9. Vaughan Hart, Art and Magic in the Court of the Stuarts (London: Routledge, 2002), 204-5. See also: Graham Parry, "Review of Art and Magic in the Court of the Stuarts," Early Modern Literary Studies 1, no. 2 (1995): 7.1-2. <URL: http:// purl.oclc.org/emls/o1-2/rev_gpi.html>

10. Stephen Orgel, The Illusion of Power (Berkeley and Los Angeles: Univ. of California Press, 1975), 72.

11. For the most current list of Jones's extant library, see Anderson, 206-300. For the list of the twenty treatises mentioned in Jones's handwritten notes, see Anderson, 301-16. Identification of the editions Jones cited is the present author's 
other hand, Stone-Heng frequently cited printed sources to support its argument; a total of sixty-seven authors provided the source material for the text, of which only a quarter belong to the list of Jones's extant library or handwritten notes. (For the list of treatises cited in Stone-Heng, please see Rumiko Handa, "Treatises Cited in The Most Notable Antiquity," Bibliographical Society of America BibSite http://www. bibsocamer .org/BibSite/bibsite.htm.) If we are to assign the intellectual content of Stone-Heng to Jones, we can then add forty-seven titles, many on Greek, Roman, or British history and mythology, to the list of works with which Jones was familiar. Such an addition must revise the way we understand the architect, as it shifts our attention from visual images to written texts. In fact, stereotyping Jones as a visual artist with little grasp of humanistic learning goes back to his own time. Ben Jonson, the poet who collaborated with Inigo Jones on court masques from 1605 to 1631 , caricatured the architect repeatedly, contrasting the poet engaged in intellectual pursuit and the architect who made mere "showes." ${ }^{2} \mathrm{We}$ know little about Jones's early years. The son of a London cloth-worker, he was said to have been apprenticed to a joiner in St. Paul's Churchyard. ${ }^{13}$ While there is evidence of opportunities for a joiner's apprentice

work. For transcriptions of Jones's annotations, see Jones on Palladio: Being the Notes by Inigo Jones in the Copy of I quattro libri dell architettura di Andrea Palladio, 1601, in the Library of Worcester College, Oxford (Newcastle-upon-Tyne: Oriel Press, 1970); Anthony W. Johnson, Three Volumes Annotated by Inigo Jones: Vasari's Lives (1568), Plutarch's Moralia (1614), Plato's Republic (Abo: Abo Akademi Univ. Printing Press, 1997); John Newman, "Inigo Jones's Architectural Education before 1614," Architectural History 35 (1992): 18-50; Gordon Higgott, “Varying with Reason': Inigo Jones's Theory of Design," Architecture History 35 (1992): 51-77; and "Inigo Jones in Provence," Architectural History 26 (1983): 21-34.

12. D. J. Gordon, "Poet and Architect: the Intellectual Setting of the Quarrel between Ben Jonson and Inigo Jones," The Renaissance Imagination, ed. Stephen Orgel (Berkeley and Los Angeles: Univ. of California Press, 1975), 77-101, 78. Ben Jonson, "Poet," Works, ed. C. H. Herford and Percy and Evelyn Simpson (Oxford: Clarendon, 1947), 8:403-4.

13. The information that Jones was apprenticed to a joiner in St. Paul's Churchyard comes from the notes of George Vertue, the eighteenth-century engraver and antiquarian, who heard it from a doctor who had in turn heard from Christopher Wren: "Dr. Harwood from Sr. Christ. Wren. says that Inigo Dy'd at Somersett house in the strand, a Roman Catholick, that he was put apprentice to a Joyner in Pauls church yard. went to Italy with the Earl of Arundel. Pembroke some say" 
to develop interests in printed books and even to be involved in publishing, biographical information about Jones often suggested that he was an architect who had no formal education but merely practical training

(British Library Add. MSS 23,069, "V. 14, B.M. 19" and "V. 14b, B.M. 19b"). See also George Vertue, The Eighteenth Volume of the Walpole Society 1929-1930: Vertue Note Books (Oxford: Oxford Univ. Press, 1930), 1:105. Although the Joiners' Company's registry of freemen has survived since 1537, that of apprentices goes back only to 1694 , making it impossible to confirm or deny Jones's apprenticeship at a joiner. (See Volume Containing Lists of Members of the Court, 1700-1906; and Alphabetical Lists of Liverymen, 1537-c.1902, with Some Notes on Their Occupations, Company Careers etc. Compiled c. 1902 by Henry Lavarock Philliips, member of the company. [Guildhall Library Manuscript Section, L.37 MS.20,589].) Although the present author's efforts to determine Jones's master as an apprentice joiner has not yielded a definitive answer, one registered master joiner has surfaced as a possible candidate: Simon Martin, a free citizen, had a "tenement shedd or little shop" in St. Paul's Churchyard. See Henry Laverock Phillips, Annals of the Worshipful Company of Joiners of the City of London: Extracted from Original Documents, Minute Books, and Renter Warden's Accounts, etc., from A.D. 1237-1850... (London: Privately printed, 1915), 10. This joiner has never been discussed in relation to Jones's apprenticeship. Martin's will, dated 25 August 1586 and proved on 8 September of the same year, is among the probate records of the Peculiar Court of the Dean and Chapter of St. Paul's in Guildhall Library Manuscript Section. A portion of this will was transcribed and included in Register Book B of the Wills Anciently Proved in the Court of the Dean and Chapter of St Pauls: "Simon Martin Citizen \& Joyner of London dated 25 Augt and proved 8 Sept 1586, After leaving 40/to the Joyners Compy and $40 /-$ to Christs Hospital and his printed books to his loving friend Gabriel Newman Citizen \& Joiner, he leaves the leases of his houses granted by the Bishop of London in St Pauls Churchyd to his wife and after her death to the Compy of Joyners," which is located "over the east side of the steppe or stayres leading into the Cathedral on the South side." The will is significant in two respects: first, if we assume the typical apprenticeship began at the age of ten to fourteen, and lasted for about seven years, Jones could have been with this joiner, but could not have completed his apprenticeship by the joiner's death. Second, the intellectual level of joiners in the late sixteenth century London (if not all then at least Martin and Newman) was such that they held a collection of printed books. However, it is also possible that Jones was apprenticed to a foreign joiner, especially an Italian one. Foreign craftsmen were exempt from London livery companies, which explains the lack of records in the registry. St. Paul's Churchyard was a central place for their businesses. See Ben Weinreb and Christopher Hibbert, London Encyclopedia (London: The Dictionary of London, 1983),760-1. Italian joiners had practiced in London, including Nicolas of Modena, who was at King Henry VIII's service, and remained in London till 1552. See also Lees-Milne, Tudor Renaissance (London: B. T. Batsford, 1951), 38-40. An apprenticeship with an Italian 
at building sites. ${ }^{14}$ Such a conclusion, in turn, has led most scholars to regard Jones's intellectual preparation as much narrower than it actually was.

joiner would explain Jones's fluency in the Italian language and culture, which led to his employment to accompany a nobleman's travel to Italy in the late 1590 .

14. St. Paul's Churchyard of the latter half of the sixteenth century was a highly fertile ground for Jones's intellectual preparation in the areas of foreign languages and cultures, classical literature, art, and architecture. By the time of Jones's presumed apprenticeship, booksellers had come to occupy many of the buildings within St. Paul's Churchyard. It was a profitable location for them, for the proximity obviously to the Cathedral but also to the Inner Temple and the Black Friars, allowing the booksellers to cater both to lawyers and clergymen, the secular and religious intellectuals of the time. (See Peter W. M. Blayney, The Bookshops in Paul's Cross Churchyard. Occasional Papers of the Bibliographical Society, no. 5. [London: The Bibliographical Society, 1990].) Two hundred and fifty-eight stationers have been identified in London between 1557 and 1640, out of which sixtynine were at St. Paul's Churchyard or immediately adjacent areas. Surrounded by many booksellers and printers, the young Jones could have had opportunities to acquaint himself in books and book business while apprenticed to a joiner. $\mathrm{He}$ could well have seen book printers, importers, sellers, and buyers all in action in those shops. The lively activities of those who crowded the area could well have motivated the young Jones in renaissance literature, classical architecture, and book collection. He might even have tried his hands in it, especially in producing woodcuts and print blocks. Woodcuts continued to be the primary method of book illustration until they were gradually replaced by copper plates. Anyone who was good at curving wood could also easily have been involved in making print blocks for letters and woodcuts for illustrations. There definitely were some joiners contemporary with Jones who did just that. The author has found, in the modern transcription of the sixteenth- and seventeenth-century registry of the Company of Stationers, a case considered out of order by the Company, in which a boy was articled not to a stationer but to a joiner, in order to learn the art of wood carving, not for building but for printing purposes (W.W. Greg, ed., A Companion to Arber, Being a Calendar of Documents in Edward Arber's Transcript of the Registers of the Company of Stationers of London, 1554-1640 [Oxford: Clarendon, 1967], 328, 333). The practice of print block making by joiners must have existed earlier, for yet another record of 1583 ordered the "joiners working on presses to be controlled by Wardens" of Stationers' Company. (For the fifteenth- and sixteenth-century woodcuts for book illustrations, see Marjorie Plant, The English Book Trade [London: George Allen and Unwin., 1974], 181-3.) An order was issued that prohibited the printers from using any print blocks made by anyone other than the Stationers' Company members. This suggests that there were many instances of joiners not members of the Company who made blocks for printing. (See also Cyprian Blagden, The Stationers' Company: A History, 1403-1959 [London: George Allen and Unwin, 1960], 25-6.) 


\section{Authorship of The Most Notable Antiquity}

In a recent study John Peacock identified many design sources including the Hercules (Illus. 1) of Francesco Albani (1578-166o), which Jones undoubtedly imitated in his 1634 design for Atlas in the masque Coelum Britannicum (Illus. 2). ${ }^{15}$ The unquestionable visual similarities, however, do not explain why Jones chose that particular image. To understand his motivation, we must turn to Pierio Valeriano's Hieroglyphics, which is cited three times in Stone-Heng but otherwise not included in Jones's reading lists based on the extant library and handwritten references. Valeriano had a short chapter titled "Coelus" in book 39, and stated in passing that another name for Coelus was "il mondo," the world. In book 59 of the same treatise, in a section added later by Caelius Augustinus, one finds a chapter titled "Hieroglyphics of the World," in which a kneeling man holding a gold sphere on his shoulders represented "il mondo" (book 59; see Illus. 3). ${ }^{16}$ It is difficult to imagine Jones choosing the same pose for a masque bearing Coelus in the title without knowing these particular associations. Additional textual sources of $\mathrm{Co}_{\mathrm{o}}$ elus's attributes include Apollodorus's Library, in which Coelus was the first of all gods $;{ }^{17}$ Diodorus Siculus's History, in which Coelus, the first king of Atlantides, performs good deeds that make him an immortal king of the world ${ }^{18}$; and Giovanni Boccaccio's Genealogy, which denies Orpheus's identification of Coelus as a huge machine adorned with stars, and instead gives a description of a "certain Man so called. Son to

15. John Peacock, The Stage Designs of Inigo Jones: The European Context (Cambridge: Cambridge Univ. Press, 1995), 14.

16. Pierio Valeriano, Ieroglifici, overo Commentari delle Occulte Significationi de gli Egittij, E d'Altre Nationi (Venice: Gio Antonio e Giacomo de' Franceschi, 1602), 596, 889. Stone-Heng (1655), 102, 105-6 cited Valeriano's bks. 39 and 60.

17. Stone-Heng (1655), 103 cited Apollodorus's bk. 1. The Latin quotation matches the text of the 1599 Greek/Latin edition: Apollodorus, Bibliotheces, sive de Deorum Origine, libri III... (Geneva: Ex off. Commeliniana, 1599), 2 (liber primus). Apollodorus's Library is not in Jones's extant library nor is it found among his handwritten notes.

18. Stone-Heng (1655), 12 and 104 cited Diodorus Siculus's bk. 6, and bk. 4. The quotations in English match the texts of the 1653 edition: Diodorus Siculus, The History of Diodorus Siculus, Containing All That is Most Memorable and of Greatest Antiquity in the First Ages of the World Until War of Troy. Done into English by H.C. Gent. (London, 1653), 235 (bk. 6, chap. 7), 150 (bk. 4, chap. 22). The equivalent passage is in the Loeb edition, trans. by C. H. Oldfather (Cambridge: Harvard Univ. Press, 1935), which has a different book/chapter configuration: vol. 3, 59 (bk. 5, chap. 21), 2:263 (bk. 3, chap. 56). 


\section{$364 \quad$ Bibliographical Society of America}

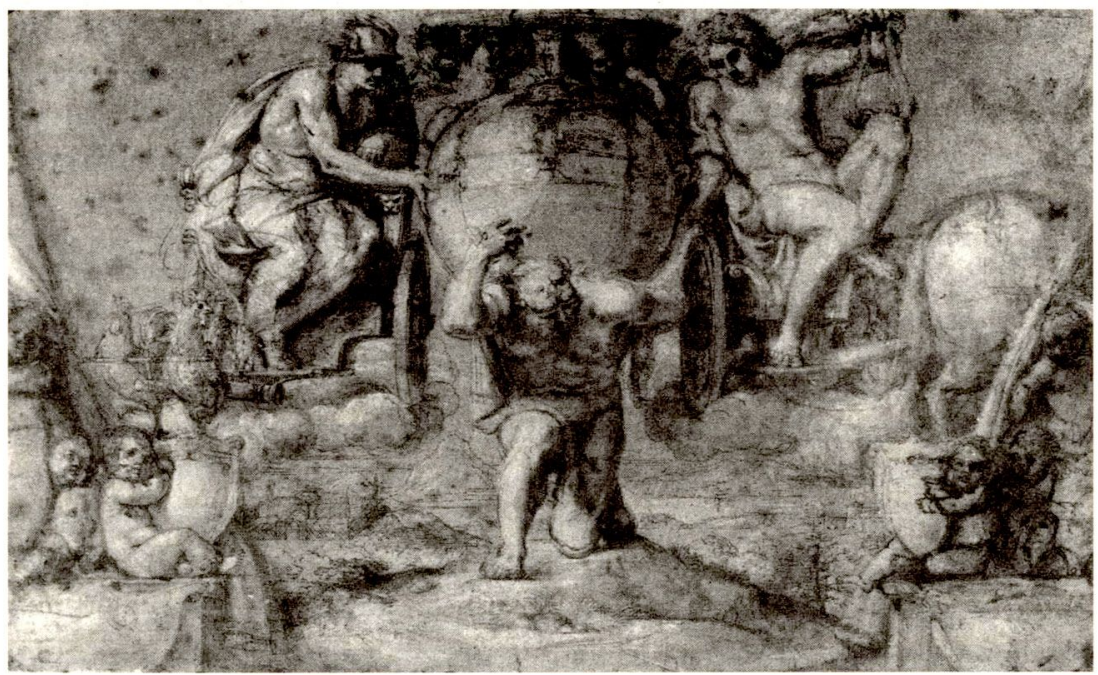

Illus. 1: Francesco Albani, Allegory of Hercules Carrying the Globe Assisted by Mercury and Apollo, Devonshire Collection, Chatsworth. Reproduced by permission of the Trustees of the Chatsworth Settlement. Photo: Photographic Survey Courtauld Institute of Art.

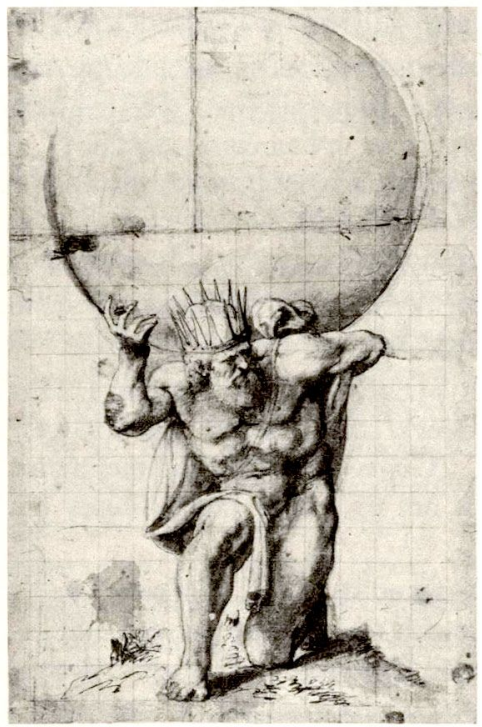

Illus. 2: Inigo Jones, Atlas, Masque "Coelum Britannicum," Devonshire Collection, Chatsworth. Reproduced by permission of the Trustees of the Chatsworth Settlement. Photo: Photographic Survey Courtauld Institute of Art. 


\section{Authorship of The Most Notable Antiquity}

Aether and Dies, that is." ${ }^{19}$ It is not so out of place for Jones to assign the above attributes of Coelus to James I, who began the House of Stuart in England, commissioned the authorized English translation of the Bible, and had a motto, "Beati Pacifici" ("Blessed are the peacemakers"). All these books are quoted directly in Stone-Heng, while, like Valeriano's Hieroglyphics, they are not among the lists of Jones's known influences.

This study makes use of two bibliographies. The first is the list of books and their editions from which quotations in Stone-Heng were drawn. In some cases there was only one edition available prior to the 1655 publication of Stone-Heng. In other cases, when multiple editions existed, the language of the quotations helps identify the most likely source. Furthermore, in some limited cases, textual or paginal discrepancies between possible editions help determine a specific edition as the source. Meanwhile, there are books and specific editions of books that we know Jones read; these books comprise the second list. For those books Jones mentioned in his handwritten notes but whose copies are not among his extant library, the specific edition is more difficult to identify; however, in those instances the same method used to more confidently identify the specific editions drawn on as sources for StoneHeng can also be applied. ${ }^{20}$

For example, as for Valeriano's Hieroglyphics mentioned above, the language of quotations - Italian - and one of the cited book numbers - "lib. 6o" - determine the possible source editions. ${ }^{21}$ Hieroglyphics was first published in Latin in Florence in $1556 .{ }^{22}$ In that same year a second, an expanded edition came out, also in Latin from

19. Stone-Heng (1655), 104 identifies Giovanni Boccaccio as "the poet."

20. For example, Jones wrote in his copy of Vitruvius's I Dieci Libri dell'Architettura, "See Suetonius fo 65:60: The aspect was Hipethros." The reference is to the 1606 English edition of Suetonius's The Historie of Twelve Caesars, Emperours of Rome, which has the appropriate text in section 60 of p. 65, but not others including a number of Latin and 1611 Italian editions.

21. Stone-Heng (1655), 105-6.

22. Giovanni Pierio Valeriano Bolzani (1477-1558), Hieroglyphicorum, ex Sacris Aegyptionum literis, Libri Octo (Florence: Lorenzo Torrentino, 1556). The 1556 Florence edition is listed in Ruth Mortimer, Harvard College Library. Department of Printing and Graphic Arts, Catalogue of Books and Mauscripts, 2 vols. (Cambridge: Harvard Univ. Press, 1974). Also see Robert G. Marshall, Short Title Catalog of Books Printed in Italy and of Books in Italian Printed Abroad, 1501-1600, Held in North American Libraries (Boston: G. K. Hall, 1970). 
Basel. ${ }^{23}$ Subsequent publications followed the 1556 Basil edition, in Latin, French (first edition: Lyon, 1576), and Italian (first edition: Venice, 1602). ${ }^{24}$ While the Basel edition consisted of fifty-eight books, two new chapters were added by Caelius Augustinus to later editions, which were in some cases identified as books 59 and 60 and in others as additional books 1 and 2. The source of Stone-Heng quotations is either the 1602 or 1625 edition in Italian, both of which carry the quotation in book $60 .{ }^{25}$

Guillaume Du Choul's Discourses of the Religions of the Ancient Romans is not directly quoted in Stone-Heng, and therefore the language is not a determining factor. However, the cited folio numbers lead to the source. The treatise was originally published in French in 1556 in Lyon; Italian and Spanish translations followed, also from Lyon. ${ }^{26}$ The book presented a new historiography based on artifacts found at the site, as opposed to second-hand oral and written transmission. According to Stone-Heng, an excavation at the site unearthed an artifact that resembled a cover of a Roman vase. Here the reference is to " $\mathrm{f}^{\circ} .217$,

23. Hieroglyphica sive de Sacris Aegy ptiorum Literis Commentarii, Ioannis Pieri Valeriani Bolzanii bellunensis. Lectori. Habes in ... (Basel: Cum gratia \& privilegio Imp. Majest. in annos quinque, 1556).

24. Among numerous later editions, Basel, 1567 (Latin); Basel, 1575 (Latin); Lyon, 1602 (Latin); Venice, 1602 (Italian); and Lyon, 1615 (French) editions consist of sixty books.

25. Giovanni Pierio Valeriano Bolzani, Ieroglifici, Ouero Commentari dell Occulte Significationi de gli Egittij, E' d'Altre Nationi (Venice: Appresso Gio. Antonio, e Giacomo de' Franceschi, 1602). The 1625 Italian edition (Venice: Presso Gio: Battista Combi, 1625). See also Frances A. Yates, Theatre of the World (Chicago: Univ. of Chicago Press, 1969), 180.

26. Guillaume Du Choul's Discourses is not in Jones's extant library, but Jones referred to Du Choul in his handwritten notes in his copy of Andrea Palladio (Venice, 1601), bk. 4, 13: "Medals of Vespasian and Titus in Choule fo. [left blank]." Stone-Heng (1655), 67 and 76 cited Du Choul's fos 5, 217, and 229. Guillaume du Choul, Discours de la Religion des Anciens Romains (Lyons: G. Roville, 1556); Discorso della Religione Antica de' Romani, trans. G. Simeoni (Lyons: G. Rovile, 1559?); Los Discursos de la Religion, Castramentacion, Banos y Exercicios de los romanos y Griegos, trans. B. Perez (Lyons: G. Roville, 1579). See also Ruth Mortimer, Harvard College Library Department of Printing and Graphic Arts, Catalogue of Books and Manuscripts, Part 1: French 16th Century Books (Cambridge: The Belknap Press of Harvard Univ. Press, 1964), 2 vols. See also Richard Cooper, "Collectors of Coins and Numismatic Scholarship in Early Renaissance France," Medals and Coins from Bude to Mommsen, ed. Michael H. Crawford, C. R. Ligota, and J. B. Trapp (London: Warburg Institute, Univ. of London, 1990), 22. 


\section{Authorship of The Most Notable Antiquity 367}

229." 27 Only the 1558 Italian edition, and neither the French nor the Spanish edition, contains the relevant illustrations, "vasetto" on page 217 and "vaso" on page 229.

Herodian's History of Roman Emperors was widely read and translated into Latin, Italian, and English, as well as French and German by $1620 .{ }^{28}$ Stone-Heng turns to Herodian twice as a source of information on the ways of life in early Britain and quotes the History of the Roman Emperors in Latin and English. Several Latin editions contain identical text and therefore the precise Latin source cannot be determined. As for the English translation, however, textual discrepancies between the four editions published before 1655 allow for a more definitive identification. Stone-Heng's quotation is:

As a rare and rich Habiliment, they wore about their Wasts and Necks Ornaments of Iron (saith he [Herodian]) and did pounce and colour their Bodies with sundry Forms, in rude manner representing several Creatures. ${ }^{29}$

Of the four English editions, 1556 has very little textual correspondence. ${ }^{30}$ The 1629 and 1635 editions, which are identical texts, have much in common with the Stone-Heng quotation:

They use not Vestures, but weare about their Wasts and Necks an Ornament of Iron; which they esteeme a rare Accoutrement, and rich Abiliment (as other Barbarians doe Gold.) They pownce and paint their Bodies with curious Pictures, and the Shapes of all sorts of Creatures. ${ }^{31}$

With an unusual syntax of "wear about (their wastes and necks) (an ornament of iron)," one can confidently conclude the 1629 or 1635 edition to be the source. The only other edition before 1655 is that of 1652 .

27. Stone-Heng (1655), 76.

28. Herodian's History is not in Jones's extant library nor is it found in his handwritten references. Stone-Heng (1655), 7 cited Herodian's bk. 3 .

29. Stone-Heng (1655) 7 .

30. The History of Herodian... translated onto of Greeke into Latin, by Augelus Politianus, and out of Latin into Englyshe, by Nicholas Smyth (London: Wyllyam Coplande, 1556 ? ), bk. 3, fol. $44^{\mathrm{r}}$.

31. Herodian of Alexandria His History of Twenty Roman Caesars and Emperors (of His Time.)...Interpreted out of the Greeke Originall (London: Printed for Hugh Perry, 1629), 176. Herodian of Alexandrea His Historie of Twenty Roman Caesars, and Emperors (of His Time.)...Interpreted out of the Greek Originall (London: Printed for Henry Taunton, 1635), 211. The texts of the 1629 and 1635 editions seem to be identical, although the page size and pagination are different. 
This text, however, is set as verse and thus does not match the StoneHeng quotation. ${ }^{32}$ It should be noted that the publication years of the possible sources are much later than 1620 , the year of King James's inquiry. The use of post-1620 editions in Stone-Heng reveals that work on the manuscript clearly continued after the King's initial inquiry. (The other two treatises post-dating 1620 will be discussed in a later section of this paper.)

\section{LANGUAGE FOR READING AND QUOTING}

As a general rule Latin was the preferred language for the Stone-Heng quotations. Certain books were available only in Latin (Bernardino Baldi, Guillaume Philander/Vitruvius, Apollodorus, William Malmesbury, Matthew Westminster, Johannes Rosinus), and it is not surprising that they were quoted in Latin with English translation. ${ }^{33}$ When a book was available both in Latin and Italian, Latin was used for quotation. Valeriano's Hieroglyphics is one of the two exceptions, the other being Giovanni Boccaccio's Genealogy. When no Latin edition had been published, no attempt was made to compose Latin sentences anew. Many English authors whose texts were available only in English fall in this category. For foreign authors with no publications in Latin, Stone-Heng either quoted in Italian (Vincenzo Scamozzi's L'idea architettura universale) or paraphrased in English. ${ }^{34}$

Meanwhile, we generally accept Jones's inadequacy in Latin and his preference for Italian. While books that have survived from his library are predominantly in Italian, there are three exceptions: two volumes in

32. Herodians of Alexandria His Imperiall History of Twenty Roman Caesars and Emperours of His Time. First Writ in Greek, and Now Converted into an Heroick Poem, by C. B. Stapylton (London: Printed by W. Hunt for the author, 1652), 101 (bk. 3 canto 12 , verse 38 ).

33. Stone-Heng's quotations match Bernardino Baldi, De Verborum Vitruvianorum Significatione (Urbino, 1612); Apollodorus, Bibliotheces (Geneve, 1599, Greek/ Latin); William of Malmesbury, De Gestis Regum Anglorum in Rerum Anglicarum Scriptores, ed. Sir Henry Savile (London, 1596); Matthew of Westminster, Praecipue de Rebus Britannicis (Frankfurt, 1601); and Johannes Rosinus, Antiquitatum Romanarum Corpus Absolutissimum (Paris, 1613; Cologne, 1619; and Geneve, 1620). None of the above are in the lists of Jones's known reading.

34. Jones's copy of Vincenzo Scamozzi, L'idea Architettura Universale (Venice, ${ }_{1615)}$ is in Worcester College Library, Special Collection. 


\section{Authorship of The Most Notable Antiquity 369}

French and one in Latin. Interestingly, the general pattern of the use of Latin quotations in Stone-Heng also a pplies to Jones's Italian books (A1berti, Caesar, Dion Cassius, Herodotus, Serlio, Strabo, Barbaro/Vitruvius). The discrepancy between the language that Jones is widely believed to have preferred and the language of the Stone-Heng quotations has sometimes been used to deny Jones's authorship or co-authorship of the text. While Jones's extant library consists predominantly of Italian books, this does not rule out Jones's reading in Latin. Rather, Jones's handwritten annotations testify to his reading of Latin texts, including Baldi's Vitruvian dictionary and Philander's commentary on Vitruvius, ${ }^{35}$ both of which were only available in Latin.

\section{DISCREPANCIES BETWEEN READING AND QUOTING}

The discrepancy between the languages of quotation and of reading does not exclude Jones as the possible author or coauthor of Stone-Heng. Quite to the contrary, such discrepancy invites speculation about a division of labor in preparing the publication in which Jones identified passages relevant to the arguments, and Webb prepared quotations for publication - guided by Jones's referential notes - and transcribed texts from an authoritative edition. This thesis may seem to differ little from Webb's statement of 1655 ; however, the specific nature of Jones's notes suggested here gives him a significant role in the intellectual construction of the book's arguments and conclusion. This is important because we can begin to regard this, the only comprehensive writing associated with Jones, as an example of how the architect's mind operated, not only in producing the treatise but also in his architectural and theatrical designs.

It was Jones's habit to make notes in margins while reading, either assimilating the text or cross-referencing other authors. A notebook survives from his $1613^{-14}$ trip to Italy, which allows us to imagine Jones keeping a similar notebook for the Stonehenge interpretation. ${ }^{36}$ The

35. Jones wrote in his copy of Serlio, "Philander in the 4 book of Vitrus: fo 189 saith in the annotations that he admonished serlio of his error tuching scima scalptura. but selio names him not." This must be in reference to the $155^{\circ}$ Latin edition and not others $(1544,1545,1549,1552,1557,1586,1649)$, which is the only edition whose fo 189 matches with the textual content being discussed.

36. Inigo Jones, Roman Notebook, or, Roma: altro diletto che imparar non trovo, MS, Devonshire Collection, Chatsworth. See also the facsimile ed. (London: Madley, 1832). 
surviving notes frequently abbreviate the authors' names, omit book titles, and sometimes fail to supply chapter or folio numbers. For example, on page 75, book 2 of his copy of Andrea Palladio's I quitri libri Jones wrote, "The Pillasters behind ye Collomes ar called Parastatice Se Vitr. Li. 3. Cap: 1." ${ }^{37}$ Some citations of the surviving handwritten references left the book, chapter, or folio number blank, like "Decorum Se Vitru: Li [left blank] fo [left blank]" on page 5, book 4 of Palladio. If we are to expect similar characteristics from Jones's Stonehenge notes, then Webb is fully justified in characterizing them as "indigested." Meanwhile, Webb is a more likely candidate for any task involving extensive knowledge of Latin. Webb attended the Merchant Taylor's School from 1625 to 1628 before joining Jones as his assistant..$^{38}$ As Jones's notes were said to be "few," it is dangerous to attribute authorship of sixty-two source notes to Jones. Instead, Webb could have identified some relevant texts himself. It is, however, more dangerous to assume that those sources that did not survive from Jones's library were all Webb's contributions.

\section{DATES OF READING AND QUOTING}

Still further evidence supporting Jones's at least partial authorship of the Stone-Heng manuscript are the likely dates of reading and quoting. The publication year of each source marks the earliest possible time of quoting, and of reading if no other editions were published earlier. Three sources post-date 1620 , the year of James I's inquiry: Herodian's editions of 1629 and 1635 discussed above, Edmund Bolton's Nero Caesar, or, Monarchie depraved - first published in $1624(\text { reprinted } 1627)^{39}$ - and

37. Andrea Palladio I quattro libri dell'architettura (Venice: Appresso Bartolomeo Carampello, 1601). Jones's copy is now in Worcester College Library, Special Collection. See also Jones on Palladio: Being the Notes by Inigo Jones in the Copy of I Quattro Libri dell Architettura di Andrea Palladio, 1601, in the Library of Worcester College, Oxford (Newcastle-upon-Tyne: Oriel Press, 1970).

38. John Bold, "Webb, John (1611-1672)," Oxford Dictionary of National Biography, ed. H. C. G. Matthew and Brian Harrison (Oxford: Oxford University Press, 2004), http://o-www.oxforddnb.com.library.unl.edu:8o/view/article/28922 (accessed November 28, 2005).

39. Edmund Bolton, Nero Caesar, or, Monarchie Depraved (London: Printed by Thomas Snodham, Bernard Alsop for Thomas Walkley, 1624). 


\section{Authorship of The Most Notable Antiquity}

the 1653 edition of Diodorus Siculus's History. ${ }^{40}$ Accordingly, we can conclude that the investigation of Stonehenge lingered years after James I's original query, and the textual preparation for publication continued after Jones's death. ${ }^{41}$

Of the two authors above, Bolton (1575?-1633?) was contemporary to Jones, and therefore Jones could have exchanged thoughts about Stonehenge in person or had access to Bolton's work in manuscript. We know that in 1606 Bolton gave Jones a copy of Bordino's De rebus praeclare gestis a Sixto V. Pon. Max (Rome, 1588), in which he praised Jones, writing:

Ignatio Jonesio suo per quem spes est, Statuarium, Plasticen, Architecturam, Picturam, Mimisim, omnenque veterum elegantiarum laudem trans Alpes, in Angliam nostram aliquando irrepturas. [Inigo Jones through whom there is hope that sculpture, modelling, architecture, painting, acting and all that is praise-worthy in the elegant arts of the ancients, may one day find their way across the Alps into our England. $]^{42}$

Bolton used a pseudonym in publications, calling himself "Philonactophil [or Philanactophil]" (friend of the king's friend), which he invented to indicate his acquaintance with Duke Buckingham. ${ }^{43}$ Respecting Bolton's anonymity by referring to him as "Anonymous" or "the translator of Florus," Stone-Heng rejected his interpretation of Stonehenge. In Nero Caesar, Bolton argued that Stonehenge was a tomb of Boadicea, who was killed in a battle by the Roman army of Suetonius Paulinus. ${ }^{44}$

The first edition of Diodorus Siculus's History was published in 1472

40. History of Diodorus Siculus Containing All That Is Most Memorable and of Greatest Antiquity in the First Ages of the World Until War of Troy, Done into English by H.C. Gent (London: Printed by John Macock, for Giles Calvert, 1653).

41. Vaughan Hart observed that Stone-Heng mentions Charles I's reign in past tense and concluded that some portion of the text was written after Charles's death in 1649 (Hart, 202). The new finding about Diodorus Siculus's English edition provides a definite proof that Stone-Heng was being written at an even later date.

42. Edmund Bolton's dedicational note to Jones is dated 30 December 1606, and this English translation is by Gotch. The book was listed by J. Alfred Gotch in Jones's extant library in Worcester College Library, but is now missing. See Gotch, Inigo Jones (London: Methuen, 1928).

43. The Roman Histories of Lucius Julius Florus, from the Foundation of Rome, Till Caesar Augustus, for above DCC Yeares, E from Thence to Traian Neare CC Yeares, Divided by Florus into IV Ages. London 1618. Jones owned an edition of Florus in Italian (Venice, 1546; colophon 1547).

44. Edmund Bolton, Nero Caesar, 181. 
(Bologna), and by 1620 the book was available in Greek, Latin, Italian, French, and English. Stone-Heng cites the treatise twice and supplied the quotations both in Latin and English. ${ }^{45}$ One of the two references concerns Coelus, the first king of Atlantides. According to Diodorus, Coelus lead his subjects from the savage state to civilization, starting agriculture and devising a calendar based on the movements of the sun, moon, and stars. Because of this, he was endowed with the honor of becoming the eternal king of the world. There were few variations in the texts of the Latin editions, and therefore we cannot determine the source, whereas the two English editions were different both in expression and content. The first English translation of Diodolus Siculus appeared in 1569 but covered later periods and did not include this section. ${ }^{46}$ The only other English translation before 1655 is that of $1653 .{ }^{47}$ This text, published after Jones's death, has close textual echoes in Stone-Heng's English quotations. This argues strongly that textual preparation of Stone-Heng continued after Jones's death, most probably by Webb. This does not make it certain, however, that Webb was responsible for identifying the relevant passage. While Jones could not have read the quoted English text, he could very well have read the book in an earlier, probably Italian edition, and identified the relevant passage. Webb's task then would have been to find in a Latin and an English edition the pertinent texts that matched Jones's referential note.

\section{BARBARO'S COMMENTARY ON VITRUVIUS}

There are two additional instances in which Webb inserts verbatim quotations, and both cases suggest that Webb was guided by Jones's referential notes. One instance is a quotation from Daniele Barbaro's translation of and commentary on Vitruvius, the first edition of which was published in 1556, in Italian, by a Venetian printer Francesco Marcolini. ${ }^{48}$ A revised edition was issued, likewise in Italian in 1567 , from

45. Stone-Heng (1655), 12, 104.

46. A Righte Noble and Pleasant History of the Successors of Alexander the Great, Taken out of Diodorus Siculus: and Some of Their Lives Written by Plutarch (London, 1569).

47. The History of Diodorus Siculus. Containing All That Is Most Memorable and of Greatest Antiquity in the First Ages of the World Until War of Troy. Done into English by H.C. Gent (London: Printed by John Macock, for Giles Calvert, 1653).

48. I Dieci Libri dell'Architettura (Venice: F. Marcolini, 1556). 


\section{Authorship of The Most Notable Antiquity}

another Venetian printer, Francesco de' Franceschi. ${ }^{49}$ Jones owned a copy of the 1567 de' Franceschi Italian edition. Barbaro also published a Latin edition in 1567 with the de' Franceschi press, which was originally planned for publication in $1556 .{ }^{50} \mathrm{In}$ this Latin text Barbaro incorporated Philander's commentaries into his own, creating some textual discrepancies from his Italian versions. ${ }^{51}$ Despite these and the language difference, the two 1567 editions have marked similarities: the woodcut on the title-page of the Italian edition appears on the verso of the titlepage of the Latin edition, and the same illustrations appear throughout both volumes. Francesco de' Franceschi published a subsequent Italian edition in 1584 . While the 1584 edition had a new title-page, its text was identical to that of the 1567 Italian edition, albeit in a different setting of type, and contained reworked illustrations.

Vitruvius is one of the most important references for Stone-Heng, and adding Barbaro's and Philander's commentaries, yielded the largest number (twenty-seven) of quotations of all the sources. All quotations except one are in Latin. This singular exception is Barbaro's commentary on open temples:

Io credo, che quel Tempio senza parrete significava alcune cose del Cielo, gli effetti delle quali sono nello scoperto:

I believe that Temple without Walls (speaking of the Monopteros aforesaid) had a Reelation to Coelum (Heaven) because the Effects thereof are openly displayed to the full View of all Men. ${ }^{52}$

The vernacular Italian makes this quotation exceptional, and there is, moreover, a good reason for it. This particular commentary of Barbaro was omitted from the 1567 Latin edition, which therefore could not provide a quotation. What makes it peculiar is that this is the only citation that specified the source edition, and furthermore, specified the 1584

49. I Dieci Libri dell'Architettura (Venice: Apresso Francesco de' Franceschi Senese, 1567). See also Louis Cellauro, "Daniele Barbaro and His Venetian Editions of Vitruvius of 1556 and 1567," Studi Veneziani (2000), 87-134.

50. D'Evelyn, Margaret Muther, "Word and Image in Architectural Treatises of the Italian Renaissance" (Ph.D. diss., Princeton University, 1994), 230.

51. De Architectura Libri Decem (Venice: Apud Franciscum Franciscium Senensem, 1567).

52. Stone-Heng (1655), 107. Both the 1567 Italian and the 1584 Italian editions have this commentary by Barbaro on p. 196. The 1567 Latin text has on p. 150 Vitruvius's statement that Barbaro refers to, but does not include Barbaro's commentary. 
edition. Since it would be more natural for Jones to refer to the 1567 Italian edition that he owned and annotated, this specification must be Webb's doing.

If we are to assume that Webb supplied the bibliographical details, shall we also assume that he was responsible for identifying the passage as well? While this is not entirely impossible, in light of all other references, it is more likely that Jones identified relevant passages in the Italian edition, and left notes. Webb was then to find the equivalent Latin passages. Webb found Latin passages that matched Jones's notes, except in this instance, and must then have resorted to the more readily available Italian edition. He must have had access to the 1584 edition and not to the 1567 Italian edition while at work, for otherwise he would have noticed the textual equivalencies between the two Italian editions. ${ }^{53}$ Also, in Webb's own publication of 1665 are several references specifically to the 1584 edition of Barbaro/Vitruvius among predominantly Latin quotations. ${ }^{54}$ The editorial work for Stone-Heng must have allowed him to realize the variation of Barbaro's texts in the different editions.

\section{ERRONEOUS CITATION OF TACITUS}

Another instance supporting the thesis of a division of labor between Jones and Webb in which Jones identifies relevant passages and Webb supplies a verbatim quotation, is the reference to Tacitus. Tacitus was

53. It is generally believed that Jones's library was inherited by Webb in its entirety, and was partially dispersed only after Webb's death; however, this is an inference made based on Webb's will. See Public Records Office PCC 145 (EURE), dated ${ }_{24}$ October 1672. See also Anderson, 183-4; and John Bold, John Webb: Architectural Theory and Practice in the Seventeenth Century (Oxford: Clarendon, 1989), 8-9. According to Anderson, the provenance of Barbaro/Vitruvius is Jones, Webb, William Barry; Lord Burlington; Devonshire Collection, Chatsworth. While "Wm Barry Lond: 1714" is clearly legible on the title-page, there is no concrete evidence for Webb's possession of the volume: What looks like "J W" immediately below Barry's signature is certainly in a hand different from Webb's: compare with Webb's signature on, for example, the drawing of the unexecuted design of the porch for Lamport Hall, 1654, in Bold, 86. The high likelihood of Webb not having an access to Jones's 1567 Italian Barbaro/Vitruvius being suggested here will in turn open the possibility that Jones's library began disintegrating before 1655 . This might explain why this particular volume, now at the Devonshire Collection, has been separated from the majority of Jones's known surviving books in the Worcester College Library, Oxford.

54. Webb, Vindication. 
published numerous times in Latin and Italian by 1600 , and the first English translation appeared in 1591, followed by the second edition of 1598. While no volume of Tacitus is in Jones's extant library and there are no direct references to Tacitus in Jones's handwritten notes, StoneHeng refers to Tacitus sixteen times, and each reference quotes the text in Latin and English. While the source Latin edition cannot be determined, the English citations are a verbatim match of the 1598 English edition. The single exception to the double language quotation is a reference to "Ann. book 16," for which no Latin counterpart accompanies the English quotation. ${ }^{55}$ In considering the reason for the lack of Latin quotation, it is curious that the English passage belongs to book 14 instead of $16 .{ }^{56}$ It is also important to note Latin editions also carry the relevant passage in book 14 .

Only a division of labor explains both Stone-Heng's erroneous book number citation and its missing Latin quotation. Jones must have read the 1598 English edition, identified the relevant passage from it, and left notes quoting the text. Meanwhile, Webb must have been charged to provide a Latin quotation guided by Jone's notes. For the quotation we are concerned with, Webb did not find an appropriate passage in a Latin edition either because he mistook Jones's handwritten citation " 14 " for "16" or because Jones erroneously noted book 16 . Webb then had to leave the quotation as Jones left it in his notes. A typographical error at the time of printing would not explain the lack of a Latin quotation.

\section{CONCLUSION: "COELUM BRITANNICUM"}

This study has compared the books and specific editions Jones read and the books and specific editions from which the Stone-Heng collaborators drew quotations. Such a comparison has yielded a number of observations upon the differences in the preferred languages for reading and quoting and the earliest possible date of reading and quoting. Several peculiar instances were also found for which a division of labor between Jones and Webb is a likely explanation. These findings in turn have led to speculation about the manner in which Jones and Webb collaborated in authoring the 1655 publication. The speculation argues in turn for an expanded understanding of Jones's intellectual background.

55. Stone-Heng (1655), 5-6.

56. The annales of Cornelius Tacitus. The Description of Germanie (London: By A. Hatfield, for Bonham and John Norton, 1598), 209 (bk. 14, section 10). 


\section{IL GIER OOLIFICO DEL MONDO:}

Li Egizziani ancora in un'altro modo con Ia effigie d'un'huomo fingeuano, \& fignificauano il mondo. Il quale formauano con i pied raccolti infieme, ueftito d'una uefte di uarij colo

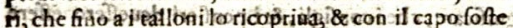
neua una sfera, o wn globorizizido d'o ro. Haueua $i$ piedi raccotti per fínificare / fernezza, \& Atábilità della terra? Ekatieftito dihuéftedunga, \&luariaspérla narietà, \& copiá de gli elemeh ril, \& delle cófe che di quelli í generano, \& dellęquali lazorra fi véfte, \& sicuopre. Gli poferg fopra il capo il globo d'oro, peril quale fi figniticaffe il cielo, di figura sferica, \& per il

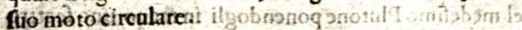

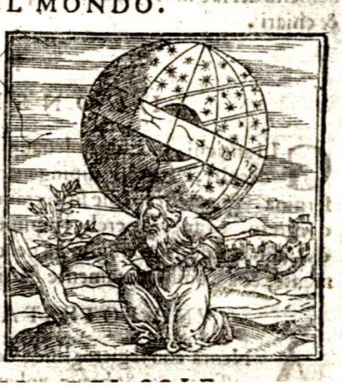

Illus. 3: Pierio Valeriano, Ieroglifici (Venice: Apresso G. A. e G. de' Franceschi, 1602), 889. Courtesy of the Newberry Library, Chicago.

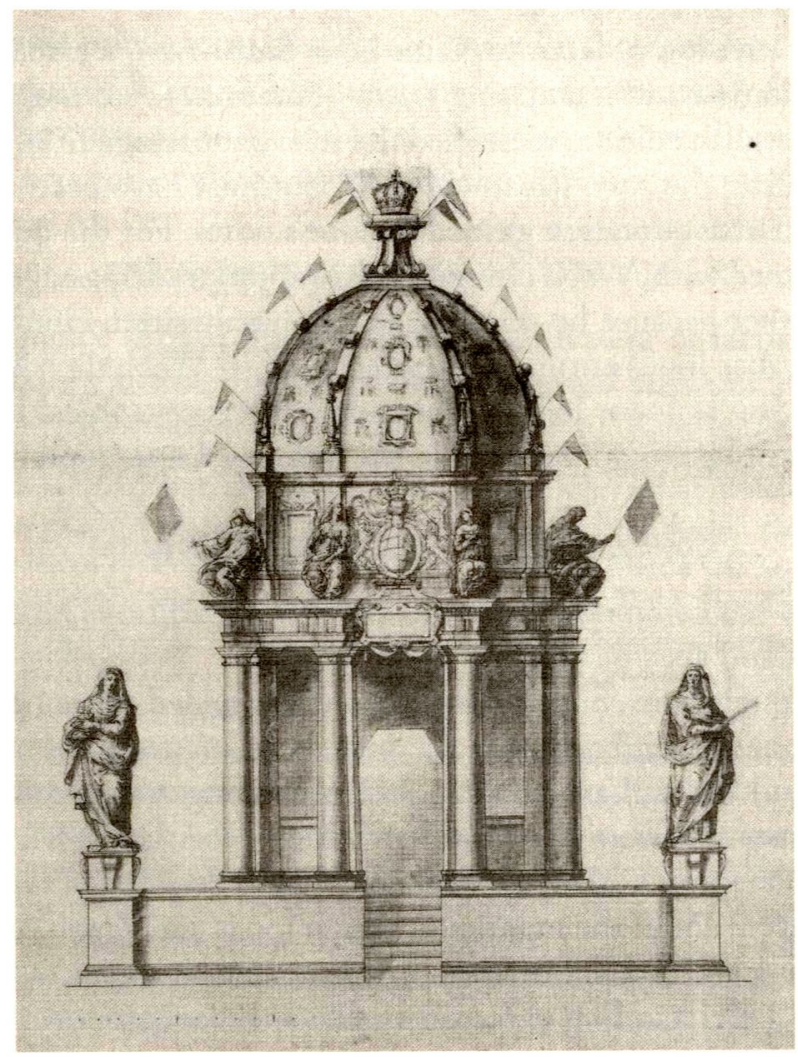

Illus. 4: Inigo Jones, Design for James I's Hearse, Worcester College Library. Courtesy of the Provost and Fellows of Worcester College, Oxford. 


\section{Authorship of The Most Notable Antiquity}

Assigning the book's content to Jones rather than to Webb gives greater significance to the symbolism of Coelus presented in Stone-Heng. The association of James with Coelus was not unprecedented. At his accession, James I processed through the City of London. For this great occasion Stephen Harrison designed triumphal arches and Thomas Dekker and Ben Jonson wrote pageants. ${ }^{57}$ Fenchurch arch in particular carried on its entablature a passage taken from Martial's epigrams, which refers to Coelum: "Par domus haec Coelo sed minor est domino" [this mansion, though it equals heaven, is less than its lord]..$^{58}$

Jones's design for the catafalque of James I of 1625 (Illus. 4) and Peter Paul Rubens's ceiling painting for the Banqueting House of the early 1630s, whose allegory Roy Strong has argued was supplied by Jones (Illus. 5), both had James I or his body situated in the middle of a circular, open temple surrounded by columns of Tuscan order, the same attributes as those Stone-Heng gave to the megalith. ${ }^{59}$ The opening scene of the masque Coelum Britannicum is a third example. Jones not only designed scenery and costumes for this masque but also had a main part in suggesting the allegories: the author, Thomas Carew, had little experience in court productions. A drawing, an unidentified scenic design by Jones (Illus. 6), not only fits the description of the beginning scene, but also, arguably, places Stonehenge in the center of its vision:

representing old arches, old palaces, decayed walls, parts of temples, theatres, basilicas and thermae, with confused heaps of broken columns, bases, cornices and statues, lying as underground, and altogether resembling the ruins of some great city of the ancient Romans or civilized Britons. ${ }^{60}$

Incredible as it may seem from a modern point of view, Stone-Heng presented the interpretation of Stonehenge as a Roman temple of Coelus, a place and deity with significant symbolic capital in the early Stuart court.

57. Stephen Harrison, The Arch's of Triumph Erected in Honor of the High and Mighty Prince. Iames. the First of That Name. King, of England. and the Sixt of Scotland (London: John Windet, 1604).

58. Martial, Epigrams, ed. and trans. D. R. Shackleton Bailey (Cambridge: Harvard Univ. Press, 1993), 2:186.

59. Roy Strong, Art and Power (Berkeley: Univ. of California Press, 1984).

6o. "Coelum Britannicum," in Stephen Orgel and Roy Strong, Inigo Jones: The Theater of the Stuart Court (Berkeley: Sotheby Parke Bernet and Univ. of California Press, 1973), 571. See also Rumiko Handa, "Coelum Britannicum: Inigo Jones and Symbolic Geometry," Nexus IV (Florence: Kim Williams Books, 2002), 109-26. 


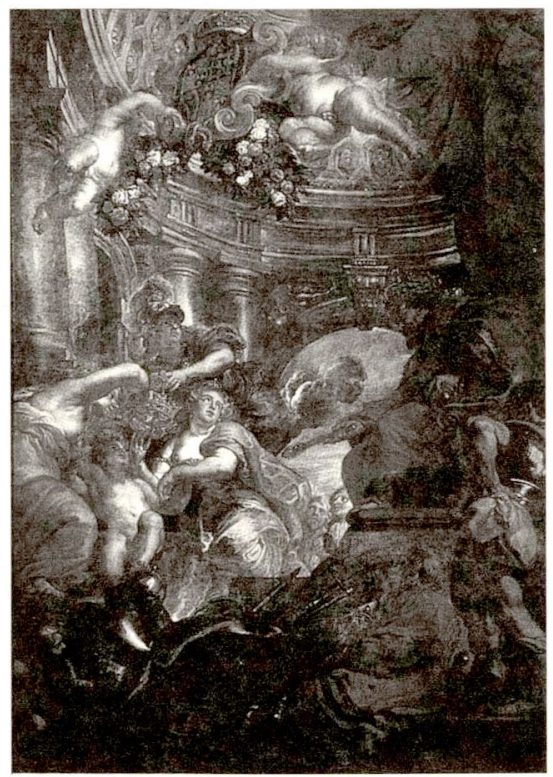

Illus. 5: Peter Paul Rubens, ceiling, The Peaceful Reign of James I, or the Benefits of His Government, Banqueting House Whitehall Palace. @ Historic Royal Palaces.

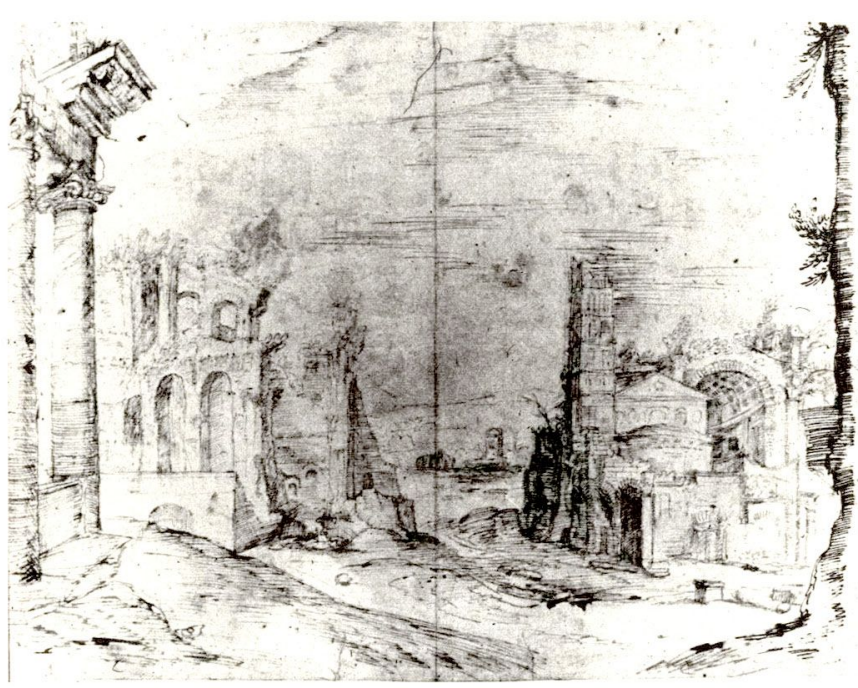

Illus. 6: Inigo Jones, Classical Ruins, unidentified masque, Devonshire Collection, Chatsworth. Reproduced by permission of the Trustees of the Chatsworth Settlement. Photo: Photographic Survey Courtauld Institute of Art. 